\begin{tabular}{llllllllllllllllll}
$\mathrm{S}$ & $\mathrm{T}$ & $\mathrm{U}$ & $\mathrm{D}$ & $\mathrm{I}$ & $\mathrm{A}$ & & $\mathrm{T}$ & $\mathrm{E}$ & $\mathrm{M}$ & $\mathrm{A}$ & $\mathrm{T}$ & $\mathrm{Y}$ & $\mathrm{C}$ & $\mathrm{Z}$ & $\mathrm{N}$ & $\mathrm{E}$ \\
\hline
\end{tabular}

STUDIA Z PRAWA WYZNANIOWEGO

Tom $21-2018$

DOI: https://doi.org/10.31743/spw.205

PIOTR STECZKOWSKI*

\title{
WSTĘP DO STUDIÓW TEMATYCZNYCH
}

Wolność sumienia i religii oraz swoboda działania związków wyznaniowych to powszechnie uznane standardy w demokratycznych i liberalnych państwach. Do tego należy dodać słuszną autonomię kościołów i innych związków wyznaniowych oraz zasadę współpracy państwa z nimi - w różnym zakresie i stopniu, w zależności od suwerennej decyzji poszczególnych państw. Wszystko to sprawia, że religie w formie zinstytucjonalizowanej są wciąż obecne w publicznej przestrzeni współczesnych państw.

Istotną formą instytucjonalizacji wyznania jest istnienie stanu duchownego. Kapłani są obecni we wszystkich najważniejszych religiach świata. Jako widzialni pośrednicy pomiędzy Bogiem (bóstwem) a ludźmi są oni podmiotami władzy religijnej, która legitymuje ich nade wszystko do sprawowania kultu religijnego oraz do przewodzenia wspólnocie religijnej. Z tych racji duchowni stanowią integralną część danego wyznania. Jednocześnie ze względu na swoją szczególną pozycję we wspólnocie religijnej mogą oni odgrywać ważne role społeczne. Historia jest przepełniona przykładami duchownych, którzy wykorzystując autorytet swojego stanu, w swoim działaniu wykraczali dalece poza mandat religijny i stawali się autentycznymi przywódcami społecznymi czy wręcz politycznymi.

Ten, wynikający z religijnej i tradycyjnej wizji status duchownego, we współczesnym świecie jest konfrontowany nie tylko z falą laicyzmu czy antyklerykalizmu, ale także z dość mocno utrwalonymi w społeczeństwach ideami egalitaryzmu prawnego i społecznego oraz koniecznego rozdziału

* Ks. dr hab., prof. UR, Katedra Nauk Historyczno i Teoretyczno-Prawnych, Wydział Prawa i Administracji, Uniwersytet Rzeszowski, ul. Grunwaldzka 13, 35-068 Rzeszów, e-mail: piotrsteczkowski@wp.pl. ORCID:0000-0002-5082-7757. 
sfery sacrum od profanum. Stąd pomysł, aby poddać prawno-naukowej refleksji przejawy tej konfrontacji. Do takiej refleksji zostali zaproszeni przedstawiciele doktryny prawa wyznaniowego z różnych ośrodków naukowych w Polsce i Słowacji. Pierwszy efekt tych prac został uwidoczniony podczas konferencji naukowej zatytułowanej Status osoby duchownej we współczesnym państwie, która odbyła się w Bańskiej Bystrzycy jesienią 2017 r., gdzie kilkunastu Autorów w wygłoszonych referatach oraz podczas ożywionej dyskusji mogło zaprezentować i skonfrontować wyniki swoich badań w tym zakresie.

Niniejszy dział tomu 21. „Studiów z Prawa Wyznaniowego” stanowi dopełnienie i drugą część zrealizowanego projektu badawczego na temat statusu duchownych we współczesnym państwie. Zaprezentowane w nim artykuły naukowe stanowią pewien przekrój tematyczny jeśli chodzi o zagadnienia szczegółowe wynikające z tematyki głównej. Większość z nich powstała w oparciu o analizę polskiego prawa w odniesieniu do duchownych przynależących do różnych wyznań czy też podejmujących działania w rozmaitych obszarach życia społecznego. Autorzy tych opracowań konfrontują przepisy prawa polskiego z przepisami prawa wewnętrznego omawianych kościołów czy związków wyznaniowych. Dzięki temu czytelnik otrzymuje spójny obraz prób harmonizacji różnych porządków prawnych. Ponadto uwypuklone zostały niektóre istotne funkcje spełniane przez duchownych realizujących religijną misję w przestrzeni publicznej i pod reżimem prawa państwowego.

Warto zwrócić uwagę na artykuły napisane z perspektywy prawnoporównawczej albo wręcz na podstawie analizy prawa obowiązującego w innych państwach. Są one cenne, gdyż poszerzają perspektywę spojrzenia na problematykę statusu prawnego osób duchownych. Całość uzupełniają dwa artykuły o charakterze historycznym, które ukazują na wycinkowych przykładach sytuację duchownych w państwie komunistycznym.

Podsumowując można stwierdzić, że problematyka statusu prawnego i funkcjonowania osób duchownych w różnych obszarach życia społecznego pozostaje nadal żywa a przedstawione podczas konferencji naukowej oraz publikowane w niniejszym tomie wyniki prowadzonych badań mogą stanowić inspirację do dalszej eksploracji tej tematyki. 